\title{
Faktor-Faktor Yang Berhubungan Dengan Kinerja Bidan Desa Sebagai Fasilitator Dalam Kegiatan Tabulin Dan Dasolin Di Kabupaten Sumenep
}

\section{The Factors Related to Performance as the Village Midwife Facilitator In Tabulin and Dasolin Activity in Planning Program Delivery and Prevention Complications (P4K) in Sumenep}

\author{
Fitriah $^{1}$, Ani Margawati ${ }^{1}$, Atik Mawarni ${ }^{1}$. \\ 1) Universitas Wiraraja Fakultas Ilmu Kesehatan Prodi D3 Kebidanan, email: fitriah_vb@ymail.com \\ ${ }^{2)}$ Fakultas Kesehatan Masyarakat, Universitas Diponegoro, Semarang
}

\begin{abstract}
Abstrak
Salah satu upaya untuk menurunkan AKI (Angka Kematian Ibu) dengan melaksanakan Program Perencanaan Persalinan dan Pencegahan Komplikasi (P4K) dalam wujud kegiatan tabulin dan dasolin yang difasilitasi bidan desa. Tujuan dari penelitian ini adalah untuk menganalisis faktorfaktor yang berhubungan dengan kinerja bidan desa sebagai fasilitator dalam kegiatan dasolin dan tabulin pada program P4K di Kabupaten Sumenep Tahun 2014.

Jenis penelitian ini adalah analitik observasional dengan design cross sectional. Variabel bebas (umur, status perkawinan, pendidikan, pengetahuan, pengalaman, motivasi dan supervisi), variabel terikat (kinerja bidan desa). Jumlah sampel 90 bidan desa yang berada di 30 puskesmas. Pengumpulan data dilakukan dengan wawancara menggunakan kuesioner terstruktur yang telah diuji validitas dan reliabilitas. Analisis bivariat dengan uji chi-square dan analisis multivariat dengan uji regresi logistik.

Hasil penelitian ini menunjukkan bahwa hampir setengahnya responden memiliki kinerja kurang (30\%), umur muda $(31,1 \%)$, status perkawinan tidak menikah $(24,4 \%)$, pendidikan kurang $(42,2 \%)$, pengetahuan kurang $(35,6 \%)$ pengalaman kurang $(77,8 \%)$, motivasi kurang $(26,7 \%)$, supervisi kurang $(24,4 \%)$ pada pengelolaan kegiatan tabulin dan dasolin diwilayah kerjanya.

Ada hubungan positif antara pengetahuan $(p=0,019)$ dan supervisi $(p=0,037)$ terhadap kinerja bidan desa sebagai fasilitator dalam pelaksanaan kegiatan tabulin dan dasolin pada program $\mathrm{P} 4 \mathrm{~K}$. Ada pengaruh bersama-sama antara pengetahuan $(p=0,07)$ dan Supervisi $(p=$ $0,013)$ terhadap kinerja bidan desa sebagai fasilitator dalam pelaksanaan kegiatan tabulin dan dasolin pada program $\mathrm{P} 4 \mathrm{~K}$.

Disarankan kepada Dinas kesehatan beserta pihak puskesmas dan IBI untuk mengadakan pelatihan dan workshop atau sosialisasi kepada bidan desa mengenai program P4K khususnya kegiatan dasolin dan tabulin.
\end{abstract}

Kata kunci : Kinerja, Kegiatan Tabulin dan dasolin, kabupaten Sumenep

Referensi : $21(1996-2012)$

\section{Abstract}

One of the efforts to decrease maternal mortality rate (MMR) was an implementation of a delivery planning and complication prevention program (P4K) in activities of delivery mother's saving and social fund for delivery conducted by village midwives. The aim of this study was to analyse factors relating to performance of a village midwife as a facilitator in the activities of delivery mother's saving and social fund for delivery on the P4K in District of Sumenep in 2014. This was an analytic-observational study using a cross-sectional approach. Independent variables consisted of age, marital status, education, knowledge, experience, motivation, and 
supervision and a dependent variable was performance of village midwives. Number of samples were 90 village midwives working at 30 health centres. Data collection used a structured questionnaire that had been performed tests of validity and reliability. Furthermore, data were analysed using methods of bivariate (Chi-Square test) and multivariate (Logistic Regression test).

The results of this research showed that respondents had low performance (30\%), young age (31.1\%), not married (24.4\%), low education (42.2\%), low knowledge (35.6\%), low experience (77.8\%), low motivation (26.7\%), and low supervision (24.4\%) in managing the activities of delivery mother's saving and social fund for delivery at their work areas.

Variables of knowledge $(p=0.019)$ and supervision $(p=0.037)$ statistically significantly related to the performance of village midwives. These two variables jointly influenced the performance of village midwives with $p$ values $=0.07$ and 0.013 respectively. District Health Office, Health Centre, and Indonesian Midwives Association need to conduct training, workshop, or socialisation to village midwives regarding the $P 4 K$ particularly the activities of delivery mother's saving and social fund for deliverydasolin.

Keywords : : Performance, Activity Tabulin and Dasolin, Sumenep District

Rbibliography : 21 (1996-2012)

\section{Pendahuluan}

Menurut Survei terakhir Demografi Kesehatan Indonesia (SDKI) tahun 2012 Angka Kematian Ibu (AKI) di Indonesia sebesar 359 per 100.000 Kelahiran Hidup (KH). Sementara target Rencana Pembangunan Jangka Menengah Nasional (RPJNM) sebesar 226 per 100.000 Kelahiran Hidup. ${ }^{1}$ Target tersebut masih jauh dari situasi derajat kesehatan di Provinsi Jawa Timuryang cenderung meningkat dalam 5 (lima) tahun terakhir, yaitu berkisar antara 7-11 point dengan data yang bersumber dari Laporan Kematian Ibu (LKI) Kabupaten/Kota. Capaian AKI dapat digambarkan sebagai berikut : pada tahun 2008 sebesar 83 per 100.000 kelahiran hidup (KH); tahun 2009 sebesar 90,7 per $100.000 \mathrm{LH}$; tahun 2010 sebesar 101,4 per $100.000 \mathrm{KH}$; tahun 2011 sebesar 104,3 per $100.000 \mathrm{KH}$; dan di tahun 2012 mencapai 97,43 per $100.000 \mathrm{KH}$. Capaian AKI Jawa Timur tahun 2012 keadaanya berada 5 point di bawah dari target MDGs tahun 2015 sebesar 102 per $100.000 \mathrm{KH}$.

Dilihat dari penyebab kematian ibu di jawa timur tahun 2010-2012 terdapat beberapa faktor. Diantaranya yaitu, pendarahan dan infeksi mengalami penurunan tahun 20102012 sedangkan faktor jantung mengalami kenaikan pada tahun 2011 sebesar $(15,47 \%)$, tetapi pada tahun 2012 mengalami penurunan sebesar (8,08\%). Dari proporsi tahun 2012, faktor Pre Eklamsia/Eklamsia masih menjadi faktor dominan $(34,88 \%)$ penyebab kematian ibu di Jawa Timur. ${ }^{2,3,4}$

Sedangkan data profil Dinas Kesehatan Kabupaten Sumenep selama tiga tahun terakhir menunjukkan bahwa Angka Kematian Ibu tercatat tahun 2010-2012 mengalami fluktuasi yaitu pada tahun 2010 mencapai 194/100.000 KH, pada tahun 2011 Angka Kematian Ibu sempat turun menjadi 117/100.000 KH, pada tahun 2012 Angka Kematian Ibu naik menjadi 119/100.000 KH sedangkan pada tahun 2013 AKI turun 2 point dari tahun sebelumnya menjadi $117 / 100.000$ $\mathrm{KH}{ }^{5,6,7}$.

Dari data Dinas Kesehatan Kabupaten Sumenep faktor penyebab Angka Kematian Ibu (AKI) selama tiga tahun terakhir tahun 2010-2012 banyak di sebabkan oleh Perdarahan sedangkan Pre Eklamsia/Eklamsia (PE/E) masih menjadi faktor kedua pada kasus kematian ibu di kabupaten Sumenep. Menurut data di Kabupaten Sumenep tempat kematian ibu terbesar terjadi di Rumah Sakit Umum $(78,18 \%)$ dan Rumah Sakit Swasta $(4,64 \%)$, hal ini berkaitan dengan system rujukan yang masih belum berjalan dengan baik. 5,6,7

Sementara itu, diketahui penyebab tak langsung dari angka kematian ibu dapat dikategorikan menjadi dua kategori. Penyebab tak langsung kematian ibu tersebut adalah "Empat terlambat" dan "Empat terlalu". 
Maksud dari "Empat terlambat" yaitu 1) Terlambat mengambil keputusan untuk dirujuk; 2) Terlambat transportasi menuju tempat rujukan; 3) Terlambat mendeteksi resiko tinggi pada ibu dan bayi; 4) Terlambat penanganan ditempat rujukan. Sementara "Empat terlalu" adalah: 1) Ibu hamil dengan usia terlalu muda $<20$ tahun; 2)terlalu tua dengan usia >35 tahun; 3) disertai jarak kehamilan yang terlalu dekat $<2$ tahun; 4) jumlah anak terlalu banyak $>4$ anak. Hal yang berkaitan dalam rangka meningkatkan cakupan mutu pelayanan kesehatan bagi ibu dan bayi baru lahir.'

Salah satu upaya Pemerintah pada tahun 2008 bahwa berdasarkan surat edaran Menkes Nomor: 294/Menkes/SE/III/2008 untuk menurunkan AKI dengan melaksanakan Program Perencanaan Persalinan dan Pencegahan Komplikasi (P4K). Program Perencanaan Persalinan dan Pencegahan Komplikasi (P4K) merupakan suatu kegiatan yang di fasilitasi oleh bidan desa dalam rangka peran aktif suami, keluarga dan masyarakat dalam persalinan yang aman dan persiapan menghadapi persalinan. ${ }^{8}$

Komponen penyelenggaraan P4K (tabulin, dasolin, ambulance desa dan pengelolaan donor darah) dilaksanakan oleh tenaga kesehatan (bidan) beserta masyarakat terdiri dari 3 unsur kegiatan yaitu peningkatan pengetahuan masyarakat tentang KIA; kegiatan pelayanan SIAGA KIA (Siap, Antar, Jaga, Kesehatan Ibu dan Anak) dari dan untuk masyarakat serta kegiatan pendukung dari pemerintah dan tokoh masyarakat dengan membentuk fokus kegiatan P4K yaitu POKJA (kelompok kerja) Tabulin (mempersiapkan tabungan ibu bersalin), Dasolin (dana sosial ibu bersalin, serta persiapan notifikasi penandaan dan pencatatan. 8,9

Hasil studi pendahuluan melalui wawancara pada 15 bidan bidan desa di Kabupaten Sumenep menunjukkan: 2 bidan desa mengatakan belum bisa mengarahkan ibu hamil dalam meyakinkan keikutsertaan tabulin dalam persiapan persalinan 4 bidan desa mengatakan tidak pernah membuat atau membentuk kegiatan dasolin dalam upaya pengumpulan uang dari anggota masyarakat sebagai dana bantuan bagi ibu bersalin dari biaya operasional desa melalui kesepakatan pertemuan bulanan tingkat desa di kecamatan. Alasan yang disampaikan oleh bidan desa mengapasebagai fasilitator kegiatan tabulin dan dasolin pada program P4K belum optimal: 2 Bidan desa mengatakan belum memahami mekanisme peran seorang fasilitator sebagai pengembangan dari kegiatan dasolin, dari segi pengelolaan dan pemanfaatan yang ditentukan dengan kesepakatan antara bidan desa,tokoh masyarakat,tokoh agama di tingkat desa dalam setiap forum di kecamatan pada program $\mathrm{P} 4 \mathrm{~K}$. 5 Bidan desa sebagai pelaksana mempunyai tugas ganda selain tugas pokok. Kurangnya pembinaan, bimbingan, pengawasan oleh bidan koordinator dalam pelaksanaan kegiatan dasolin, tabulin, serta dua bidan desa diantaranya mengatakan penempatan desa yang terpencil jauh dari daratan menjadi kendala. Yang menyebabkan mereka malas datang dalam setiap kesepakatan pertemuan rutin bulanan tingkat desa di kecamatan.

Sedangkan hasil dari informasi wawancara pada 3 tokoh masyarakat sebagai berikut, Sebanyak 3 tokoh masyarakat mengatakan bidan desa saat menjadi fasilitator desa kurang merespon serta kurang menciptakan pemahaman tentang upaya pelaksanaan forum kegiatan $\mathrm{P} 4 \mathrm{~K}$ (tabulin, dasolin) dimasyarakat.

Berdasarkan hasil studi pendahuluan ditemukan bahwa masih ada bidan desa sebagai fasilitator belum sesuai dengan pelaksanaan kegiatan tabulin dan dasolin pada program perencanaan persalinan dan pencegahan komplikasi (P4K). Pengelolaan kegiatan tabulin dan dasolin akan berdampak menurunkan kematian ibu dengan pelaksanaan yang cepat dan tepat, sehingga dapat mencegah kematian ibu yang dikarenakan Empat terlambat" dan "Empat terlalu". Maksud dari "Empat terlambat" yaitu 1) Terlambat mengambil keputusan untuk dirujuk; 2) Terlambat transportasi menuju tempat rujukan; 3) Terlambat mendeteksi resiko tinggi pada ibu dan bayi; 4) Terlambat penanganan ditempat rujukan.

Tujuan dari penelitian ini adalah untuk menganalisis faktor-faktor yang berhubungan dengan kinerja bidan desa sebagai fasilitator dalam kegiatan tabulin dan dasolin di Kabupaten Sumenep tahun 2014. 


\section{Metode Penelitian}

Jenis ini adalah analitik observasional yaitu menjelaskan hubungan antara variabel bebas (umur, status perkawinan, pendidikan, pengetahuan, pengalaman, motivasi dan supervisi), antara variabel terikat (kinerja bidan desa). Penelitian ini adalah studi Kuantitatif dengan pendekatan cross secsional yaitu pengukuran melalui kuesioner terstruktur dan menggunakan cek list pada variabel penelitian dilakukan hanya satu kali pada saaat yang sama. ${ }^{10}$

Populasi penelitian ini adalah bidan puskesmas di Kabupaten Sumenep sejumlah 360 bidan desa di Kabupaten Sumenep. Besar Sampel didapatkah sejumlah 90 bidan desa. Pengambilan sampel mengunakan metode purposive sampling dengan menggunakan kriteria inklusi pada sampel.

Pengambilan data dengan cara wawancara dan pengamatan mengunakan kuesioner terstruktur. Sebelum melakukan penelitian kuesioner dilakukan uji validitas dan reliabilitas terlebih dahulu dengan mengujikan kuesioner kepada 30 bidan desa yang berada Kabupaten pamekasan.

Sebelum menganalisis data dilakukan terlebih dahulu uji normalitas data menggunkan uji kolmogorov smirnov (sampel $>50$ ). Analisis data yang digunakan dalam penelitian ini ada anlisis univariat (tabel frekuensi), anlisis bivariat (uji hubungan), dan multivariat (menguji secara bersama-sama variabel bebas terhadap variabel terikat) dengan menggunkan uji regresi logistik.

\section{Hasil}

\section{Karakteristik Responden}

Dalam penelitian ini responden yang digunakan adalah bidan desa Kabupaten Sumenep, Sebagian besar responden berpendidikan >D1 Kebidanan 57,8 \%, ratarata usia responden adalah $>25$ tahun dengan memiliki status pernikahan tidak menikah/janda Berdasarkan hasil analisis variabel bebas dan variabel terikat dapat dilihat pada grafik berikut ini :

Hubungan antara Variabel Bebas dengan Variabel Terikat :

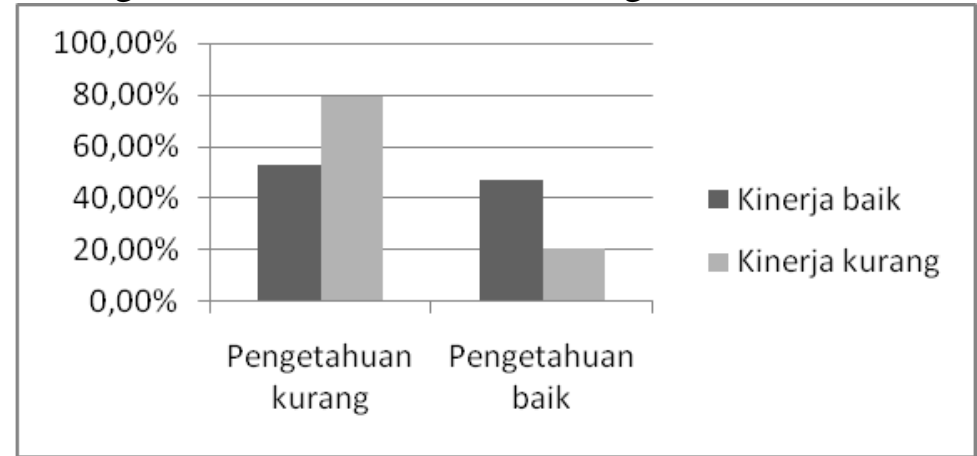

Grafik 1.1. Hubungan Pengetahuan Dengan Kinerja Bidan Desa

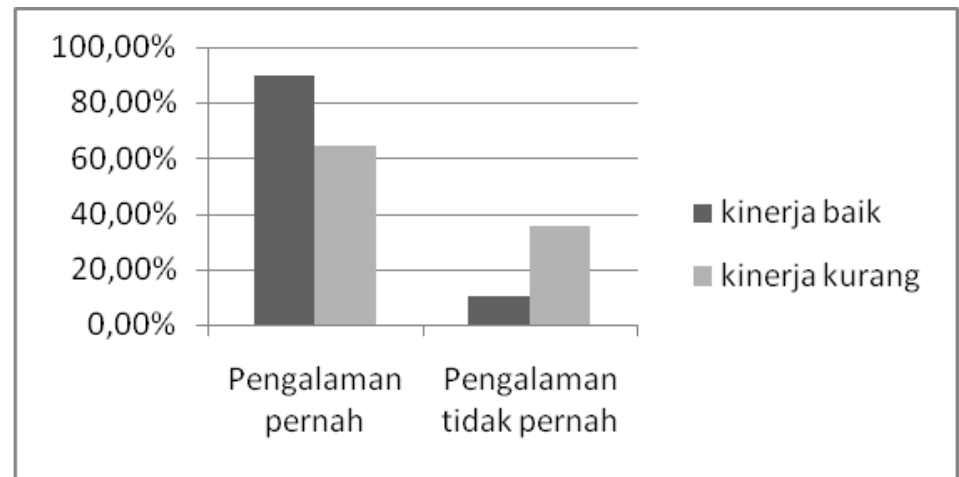

Grafik 1.2. Hubungan Pengalaman Dengan Kinerja Bidan Puskesmas 


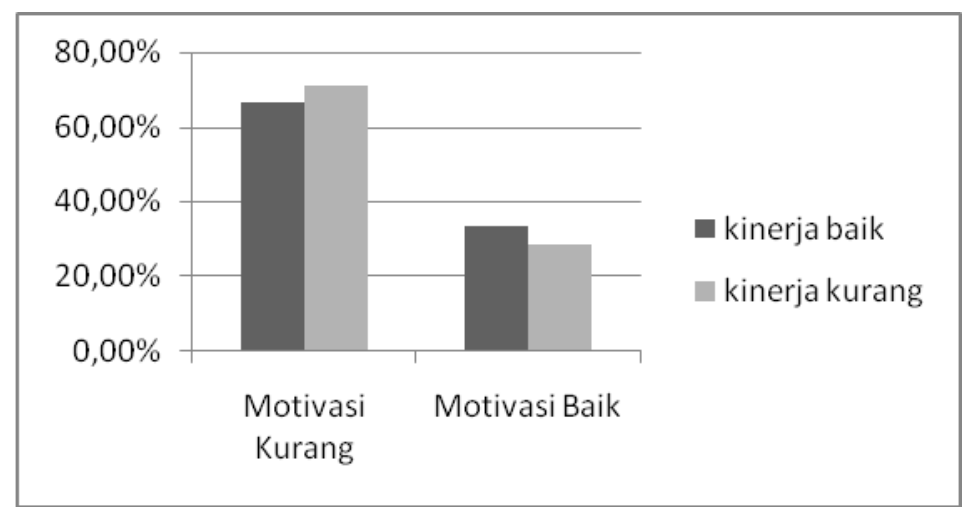

Grafik 1.3. Hubungan Motivasi Dengan Kinerja Bidan Desa

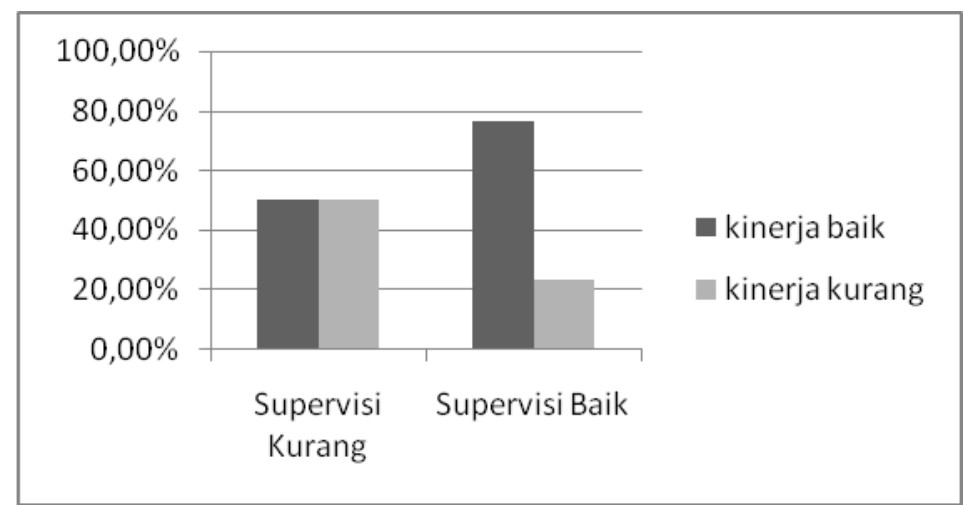

Grafik 1.4. Hubungan Supervisi Dengan Kinerja Bidan Desa

Variabel bebas dan variabel terikat dilakukan uji chi-square dengan hasil sebagai berikut yang dapat dilihat pada tabel 1.1:

Tabel 1.1 Hasil Uji Hubungan Dengan Menggunkan Chi-Square Variabel Bebas Terhadap Variabel Terikat

\begin{tabular}{clcl}
\hline No & \multicolumn{1}{c}{ Variabel bebas } & Nilai p & \multicolumn{1}{c}{ Keterangan } \\
\hline 1 & Umur & 0,585 & Tidak Berhubungan \\
\hline 2 & Status Perkawinan & 0,556 & Tidak Berhubungan \\
\hline 3 & Pendidikan & 0,056 & Tidak Berhubungan \\
\hline 4 & Pengetahuan & 0,019 & Berhubungan \\
\hline 5 & Pengalaman & 0,053 & Tidak Berhubungan \\
\hline 6 & Motivasi & 0,876 & Tidak Berhubungan \\
\hline 7 & Supervisi & 0,037 & Berhubungan \\
\hline
\end{tabular}

Dari tabel 1.1 menunjukkan bahwa variabel yang memiliki hubungan dengan variabel terikat adalah: pengetahuan, supervisi sedangkan umur, status perkawinan, pendidikan pengalaman, motivasi tidak ada hubungan dengan kinerja bidan desa dalam kegiatan tabulin dan dasolin pada program P4K.

Dari hasil uji hubungan tersebut dilakukan uji multivariat untuk mengetahui varibel yang berpengaruh secara bersamasama dengan variabel terikat dengan menggunakan uji Regresi Logistik multivariat diperoleh bahwa variabel bebas yang dianggap terbaik untuk kinerja bidan desa dalam kegiatan tabulin dan dasolin pada program $\mathrm{P} 4 \mathrm{~K}$, dapat dilihat pada tabel berikut ini :

Tabel 1.2. Uji Regresi Logistik Multivariat

\begin{tabular}{lccc}
\hline Variabel penelitian & Sig & $\operatorname{Exp}(\mathrm{B})$ & $\mathrm{R}^{2}$ \\
\hline Pengetahuan & $0,007^{\mathrm{c}}$ & 4,011 & \multirow{2}{*}{0,194} \\
Supervisi & $0,013^{\mathrm{c}}$ & 3,981 &
\end{tabular}

${ }^{C}$ : Uji Regresi Logistik 


\section{Pembahasan}

Pada grafik 1.1 hubungan pengetahuan dengan kinerja bidan desa dalam kegiatan tabulin dan dasolin pada program P4Kmenunjukkan bahwa bidan desa dengan pengetahuan baik sebagian besar kinerjanya baik sedangkan bidan desa yang memiliki pengetahuan kurang sebagian besar kinerja kurang dalam kegiatan tabulin dan dasolin pada program $\mathrm{P} 4 \mathrm{~K}$. Uji chi-square didapatkan hasil $\mathrm{p}=0,019$ artinya ada hubungan positif pengetahuan dengan kinerja bidan desa dalam kegiatan tabulin dan dasolin pada program P4K.

Pengetahuan adalah kemampuan intelektual responden yang mencakup pemahaman materi. Pengetahuan merupakan proses mencapai tahu, dari yang tadinya tidak tahu menjadi tahu, dari tidak dapat menjadi dapat. Dalam proses mencari tahu ini mencakup berbagai metode dan konsepkonsep. ${ }^{11}$ Pengetahuan yang di miliki bidan desa mempunyai kewajiban menjalankan perannya untuk membantu dan melayani masyarakat khususnya padakegiatan tabulin dan dasolin pada program $\mathrm{P} 4 \mathrm{~K}$ sangat bermanfaat bagi bidan desa dalam menjangkau penyebab terjadinya tak langsung kematian pada ibu adalah Empat terlambat pada ibu hamil maupun ibu bersalin.

Pada grafik 1.2 hubungan pengalaman dengan kinerja desa dalam kegiatan tabulin dan dasolin pada program P4K menunjukkan bahwa bidan desa yang pernah memiliki pengalamanbaik dalam kegiatan tabulin dan dasolin pada program $\mathrm{P} 4 \mathrm{~K}$ hampir seluruh kinerjanya baik sedangkan bidan desa yang tidak pernah memiliki pengalaman dalam kegiatan tabulin dan dasolin pada program P4K kinerjanya kurang. Hasil uji chi-square didapatkan hasil $\mathrm{p}=0,053$ artinya ada hubungan negatif pengalaman dengan kinerja bidan desa dalam kegiatan tabulin dan dasolin pada program $\mathrm{P} 4 \mathrm{~K}$.

Berdasarkan teori Hal ini dikarenakan salah satu kelebihan dari sifat manusia dibandingkan dengan mahkluk lain adalah kemampuan belajar dari pengalaman yang telah didapat terutama didalam pengalaman yang berakhir pada kesalahan. ${ }^{15}$ Sebagian berpendapat bahwa pengalaman seseorang dalam melakukan tugas tertentu secara terus menerus dalam waktu yang cukup lama dapat meningkatkan kedewasaan teknisnya. ${ }^{13}$

Pada grafik 1.3 hubungan motivasi dengan kinerja bidan desa dalam kegiatan tabulin dan dasolin pada program P4K menunjukkan bahwa bidan desa yang memiliki motivasikurang kinerjanya kurang sedangkan bidan desa yang memiliki motivasi baik kinerjanya baik. Hasil uji chi-square didapatkan hasil $\mathrm{p}=0,876$ artinya ada hubungan negatif motivasi dengan kinerja bidan desa dalam kegiatan tabulin dan dasolin pada program $\mathrm{P} 4 \mathrm{~K}$.

Berdasarkan teori Moekijat, motivasi adalah keadaan dari pribadi seseorang yang mendorong keinginan individu untuk melakukan kegiatan tertentu guna mencapai tujuan. Motivasi yang ada pada seseorang merupakan kekuatan pendorong yang akan mewujudkan suatu perilaku guna mencapai tujuan kepuasan dirinya. ${ }^{16}$ Motivasi dalam hubungan seseorang dengan pekerjaannya itu merupakan hal yang mendasar. Handoko (1998) menyatakan motivasi adalah keadaan dari pribadi seseorang yang mendorong keinginan individu untuk melakukan kegiatan tertentu guna mencapai tujuan. ${ }^{21}$

Pada grafik 1.4 hubungan supervisi dengan kinerja desa dalam kegiatan tabulin dan dasolin pada program $\mathrm{P} 4 \mathrm{~K}$ menunjukkan bahwa bidan desa yang menerima supervisi kurang memiliki kinerja kurang sedangkan bidan desayang menerima supervisi baik memiliki kinerja baik. Hasil uji chi-square didapatkan hasil $\mathrm{p}=0,037$ artinya ada hubungan positif supervisi dengan kinerja bidan desa dalam kegiatan tabulin dan dasolin pada program $\mathrm{P} 4 \mathrm{~K}$. Hal ini menunjukkan bahwa supervisi merupakan salah satu faktor untuk menentukan kinerja bidan desadalam kegiatan tabulin dan dasolin pada program $\mathrm{P} 4 \mathrm{~K}$.

Berdasarkan teori bahwa Perilaku kerja yang ditunjukan oleh karyawan sesungguhnya merupakan gambaran atau cerminan sikap seseorang, apabila sikap itu positif sejak awal dikembangkan oleh individu maka perilaku kerja yang timbul adalah baik, dengan perilaku kerja yang positif maka akan mewujudkan kinerja yang tinggi bukan pekerjaaan yang susah. ${ }^{15}$ 
Variabel bebas yang berhubungan dengan kinerja desa dalam kegiatan tabulin dan dasolin pada program $\mathrm{P} 4 \mathrm{~K}$ adalah pengetahuan dan supervisi. Kemudian untuk mengetahui variabel bebas yang berpengaruh secara bersama-sama terhadap variabel terikat dilakukan uji Multivariat menggunkan uji Regresi Logistik.

Berdasarkan 1.2 menunjukkan bahwa variabel penelitian yang berpengaruh secara bersama-sama adalah pengetahuan dan supervisi dalam kegiatan tabulin dan dasolin pada program P4K. Faktor yang mempunyai pengaruh terbesar dalam kinerja bidan desa dalam dalam kegiatan tabulin dan dasolin pada program $\mathrm{P} 4 \mathrm{~K}$ adalah pengetahuan bidan desa dengan nilai $\operatorname{Exp}(B)=4,011$, selanjutnya di ikuti oleh supervisi bidan desa dengan nilai $\operatorname{Exp}(B)=3,981$.

Pengetahuan bidan desa yang baik akan meningkatkan kinerja bidan puskesamas dalamdalam kegiatan tabulin dan dasolin pada program P4K sebesar 4,011 kali lebih besar daripada pengetahuan yang kurang, sedangkan supervisi yang baik akan meningkatkan kinerja bidan desa dalam dalam kegiatan tabulin dan dasolin pada program P4K 3,981 kali lebih besar dibandingkan dengan supervisi yang kurang.

Kontribusi pengetahuan dan supervisi pada bidan desa terhadap kinerja dalam dalam kegiatan tabulin dan dasolin pada program P4K dapat dilihat dari nilai $\mathrm{R}^{2}$ pada tabel 4.20. nilai $\mathrm{R}^{2}=0,190$ artinya pengetahuan dan supervisipada bidan desa berkontribusi terhadap kinerja bidan puskesmas desa dalam kegiatan tabulin dan dasolin pada program P4K di Kabupaten Sumenep sebesar 13,4\% sedangkan $86,6 \%$ disumbang oleh faktor lain yang tidak dianalisis.

Hal ini menunjukkan bahwa untuk meningkatkan kinerja bidan desa sebagai fasilitator dalam pelaksanaan kegiatan tabulin dan dasolin pada program $\mathrm{P} 4 \mathrm{~K}$, maka perlu ditingkatkannya pengetahaun dan supervisi yang baik secara bersama-sama. Berdasarkan teori Kinerja, Kinerja merupakan penampilan hasil kerja personal baik kualitas dalam suatu organisasi kinerja berupa penampilan individu maupun kelompok kerja personil, tidak terbatas kepada personal yang memangku jabatan struktural maupun fungsional. Dalam kinerja (job performance) tercakup sejumlah hasil, yaitu hasil obyektif dan hasil perilaku pribadi. Hasil objektif berupa kuantitas dan kualitas keluaran sesuai dengan tugas dan standar masing-masing pemegang pekerjaan. Hasil perilaku pribadi berupa reaksi terhadap pekerjaan: hadir secara teratur atau mangkir, tetap bekerja atau berhenti. Lebih lanjut masalah fisiologi dan psikologi dapat menjadi konsekuensi kinerja. ${ }^{14}$

Menurut Gibson ada tiga faktor yang berpengaruh terhadap kinerja, yaitu: faktor individu, faktor psikologis dan faktor organisasi. Faktor individu salah satu unsurnya adalah pengetahuan sedangkan faktor organisasi salah satu unsurnya adalah supervisi. Notoatmojo berpendapat bahwa pengetahuan merupakan hasil dari tahu, dan ini terjadi setelah orang melakukan pengindraan terhadap suatu obyek tertentu, dari pengalaman dan penelitian terbukti bahwa perilaku yang didasari oleh pengetahuan akan lebih langgeng daripada perilaku yang tidak didasari oleh pengetahuan. ${ }^{19}$ Pendapat lain Mangkuprawiro menyatakan bahwa pengetahuan merupakan sebuah derajat di mana karyawan disyaratkan untuk mengetahui secara teknis apa yang dikerjakannya. ${ }^{20}$

Menurut Azwar supervisi adalah kegiatan pembinaan, bimbingan dan pengawasan oleh pengelola program terhadap pelaksana ditingkat administrasi yang lebih rendah dalam memantapkan pelaksanaan kegiatan sesuai dengan tujuan dan sasaran yang telah ditetapkan. Supervisi adalah melakukan pengamatan secara langsung dan berkala oleh atasan terhadap pekerjaan yang dilaksanakan oleh bawahan apabila ditemukan masalah diberikan petunjuk atau bantuan yang bersifat langsung guna mengatasinya. ${ }^{17}$

Supervisi dapat dilakukan melalui dua cara yaitu Cara langsung Supervisi dilakukan secara langsung pada kegiatan yang sedang berlangsung. Cara tidak langsung Supervisi dilakukan melalui laporan baik tertulis maupun lisan. Supervisi tidak melihat langsung apa yang terjadi dilapangan, sehingga mungkin terjadi kesenjangan fakta. Umpan balik dapat diberikan secara tertulis. Supervisi kepada bidan desa, dilakukan oleh kepala puskesmas melalui Bidan Koordinator (bikor) yang berperan sebagai penyedia. 
Dalam penyediaan bikor dapat menerapkan beberapa cara untuk menilai kemampuan dan keterampilan serta kepatuhan bidan desa. ${ }^{18}$

Oleh karena itu dengan hasil multivariat tersebut maka untuk meningkatkan kinerja bidan desa dalam kegiatan tabulin dan dasolin pada program P4K di Kabupaten Sumenep perlu ditingkatkannya secara bersama-sama variabel pengetahuan dan supervisi pada bidan desa dalam kegiatan tabulin dan dasolin pada program $\mathrm{P} 4 \mathrm{~K}$ sehingga angka kematian ibu yang diakibatkan oleh terlambat mengambil keputusan untuk di rujuk serta terlambat mendeteksi resiko tinggi pada saat kehamilan agar dapat segera diatasi.

\section{Kesimpulan}

Ada hubungan positif pengetahuan bidan desa $(p=0,019)$ dengan kinerja bidan desa dalam dalam kegiatan tabulin dan dasolin pada program $\mathrm{P} 4 \mathrm{~K}$, ada hubungan positif supervisi bidan desa $(p=0,037)$ dengan kinerja bidan desadalam kegiatan tabulin dan dasolin pada program P4K.

Ada hubungan negatif pengalaman $(\mathrm{p}=0,053)$ dengan kinerja bidan desa dalam kegiatan tabulin dan dasolin pada program P4K. Motivasi tidak ada hubungan dengan kinerja bidan desa dalam kegiatan tabulin dan dasolin pada program P4K. Variabel bebas yang paling penting terhadap kinerja bidan desa dalam kegiatan tabulin dan dasolin pada program $\mathrm{P} 4 \mathrm{~K}$ adalah pengetahuan $(\mathrm{p}=0,007$; $\operatorname{Exp}(B)=4,011) \quad$ dan supervisi $\quad(p=0,13$; $\operatorname{Exp}(B)=3,981)$.

\section{DAFTAR PUSTAKA}

1. Depkes RI. Upaya Akselerasi Penurunan AKI. Jakarta. Depkes RI.

2. Dinkes. Profil Kesehatan JawaTimur. Surabaya; 2010.

3. Dinkes. Profil Kesehatan Jawa Timur. Surabaya; 2011.

4. Dinkes.Profil Kesehatan JawaTimur. Surabaya; 2012.

5. Dinkes.Kab.Sumenep, Laporan Tahunan. Binkesmas; 2010.

6. Dinkes.Kab.Sumenep, Laporan Tahunan. Binkesmas; 2011.

7. Dinkes.Kab.Sumenep, LaporanTahunan. Binkesmas; 2012.
8. Dinkes. PropJatim. Pedoman Program Pelaksanaan Perencanaan Persalinan (Pedoman Bagi Bidan). Jakarta; 2009.

9. Dinkes. Prop Jatim. Modul Motivator Program Perencanaan Persalinan (Pedoman Bagi Kader). Jakarta; 2009.

10. PNPM. Petunjuk teknis Operasional Program Nasional Pemberdayaan masyarakat. Jakarta.

11. YPKP. Perspektif Gender dan Ham dalam Asuhan Kebidanan Komunitas. Jakarta; 2000.

12. Depkes RI. Petunjuk Penilaian Kinerja Bidan di Desa / PTT. Jakarta; 2003.

13. Depkes RI. Buku Saku Bidan di Desa. Binkesmas : Jakarta; 1996.

14. Gibson.Organisasi Perilaku Struktur Dan Proses Vol.2. Jakarta: Binarupa Aksara; 1996.

15. Sudarmanto. Kinerja dan Pengembangan Kompetensi SDM. Jakarta; Pustaka Pelajar; 2009.

16. Moekijat. Manajemen Sumber Daya Manusia (Manajemen Kepegawaian); Bandung: Mandar Maju; 1999.

17. A, Azwar. Pengantar Administrasi Kesehatan. Jakarta: Binarupa Aksara; 2010.

18. Depkes RI. Pedoman Bidan Koordinator Tingkat Puskesmas. Jakarta; 2008.

19. Notoatmodjo, Soekidjo. Promosi Kesehatan Teori dan Aplikasi. Jakarta: Rineka Cipta; 2005.

20. Mangkuprawira, Sjafri. Manajemen Sumber Daya Manusia Strategik. Bogor: Ghalia Indonesia; 2011.

21. Anonim. Kajian Ekonomi, Manajemen dan Akuntansi. STEI. Jakarta. 